\title{
Dönüşüm Geometrisi Konusunun Öğretimi İçin Geliştirilen Dönüşüm Çarkı Materyalinin Kullanılabilirliğinin İncelenmesi
}

Analyzing of Usability of Transformation Wheel Material Developed for Teaching Transformation Geometry

\section{Elif Bahadır \& İrem Demir}

Matematik ve Fen Bilimleri Eğitimi Bölümü, Yıldız Teknik Üniversitesi, İstanbul, Türkiye

\section{Özet}

Günümüz eğitim sisteminde öğrenci, öğrenme ortamının nesnesi olmaktan çıkıp öznesi haline gelmeye başlamıştır. Öğrencilerin derse aktif katılımını sağlayacak stratejiler günümüz eğitiminde çok daha önemli hale gelmiştir. Bu çalışmada öğrencilerin aktif olarak katılarak dönüşüm geometrisi konusunu çalışabilecekleri "Dönüşüm Çarkı" materyalinin kullanılabilirliği incelenmiştir. Çalışmamız 7. Sınıf matematik dersi müfredatında bulunan Dönüşüm Geometrisi konusunun kazanımlarına uygun olarak tasarlanmış "Dönüşüm Çarkı" materyalinin kullanılabilirliğinin incelenmesi ve geliştirilen materyalle ilgili öğretmen ve öğrenci görüşlerinin belirlenmesi amacıyla yapılmıştır. Bu amaçla, araştırma istanbul ilindeki bir ortaokulun 7. Sınıfından 21 öğrenci ve materyalin tanıtıldı̆ı 9 matematik öğretmeni ile gerçekleştirilmiştir. Çalışmada aksiyon araştırma yöntemi kullanılmıştır. Öğrencilere Dönüşüm Çarkı materyali ile dönüşüm geometrisi konusu anlatılmış konuyla ilgili çalışma kâğıtları dağıtılarak çalışma kâğıtlarında konuyla ilgili olan cevaplarını dönüşüm çarkı materyallerinden kontrol etmeleri istenmiş ve her öğrencinin materyali kullanması sağlanmıştır. Uygulama sonrasında materyalle ilgili olarak her bir öğrenciden görüşleri yazılı olarak alınmıştır. Öğretmenlerin materyalin kullanılabilirliğine ilişkin düşünceleri alınmıştır. Öğretmenlerden çoğunun, materyali uygulanabilir bulduğu ve beğendiği bulgusuna ulaşımıştır. Çalışmanın sonucunda matematiksel kavramların öğretiminde ya da öğrenilen kavramları somutlaştırmada dönüşüm çarkı somut materyalinin etkili olduğu, öğrenci görüşmelerinden ve araştırmacıların gözlemlerinden elde edilen bulgulardan anlaşılmaktadır. Öğrenci merkezli olarak uygulanması, öğrencilere analitik düşünme ve sosyal etkileşim becerisi kazandırması özellikleri materyalin kullanışlılığını ve konunun anlaşılabilirliğine katkı sağlamaktadır. Bu kapsamda dönüşüm çarkı somut materyalinin matematik öğretiminde kullanılabilir nitelikte olduğu sonucuna varılmıştır.

Anahtar Kelimeler: Matematik eğitimi, Dönüşüm geometrisi, Materyal

CONTACT : Elif Bahadır, elfbahadir@gmail.com

Geliş Tarihi \& First Received : 29.03.2017

Kabul Tarihi \& Accepted : : 09.06.2017 


\begin{abstract}
In today's education system, students began to be the subject of the learning environment instead of to be the object of it. Strategies that will provide student participation in the courses also have become even more important in today's education. In this study, the usability of "Transformation Wheel" material that students can work actively participating in the subject of transformation geometry was analyzed. Our study was conducted with the aim of analyzing the usability of "Transformation Wheel" material designed in accordance with the acquisitions of 7 th grade mathematics course curriculum about Transformation Geometry and determining the teachers and students' opinions about developed material. For this purpose, the research was carried out with 21 7th graders from a middle school and 9 math teachers who were introduced the material in Istanbul province. In the study, action research method was used. The students were presented to the subject of Transformation Geometry with Transformation Wheel material, then were given worksheets and asked to check their answers that are related to the subject from the Transformation Wheel material. With this way, each student was provided to use the material. After the application, each student's views regarding the material were taken in written. The views of the teachers were also received about the material. And most of the teachers found it to be usable and liked it. As a result of the study, in teaching of mathematical concepts or objectifying the learned concepts, the Transformation Wheel material was found to be effective. It was also determined that it had been applied as studentcentered and had gained students analytical thinking and social interaction skills. In this context, the concrete material of Transformation Wheel was inferred to be usable for teaching mathematics.

Keywords: Mathematics education, Transformation geometry, Material
\end{abstract}

\title{
Extended Abstract
}

\section{Introduction}

In today's rapidly changing and globalized world, individuals are not expected to receive information from a single source and memorize it. Conversely, the individuals who can know how to obtain information and can use them and can create solution methods for the problems they faced using the information are aimed to be trained. In the educational environment, the student's developing different skills such as; problem-solving, communication, reasoning and correlating skills are also aimed. In individuals' acquiring these characteristics and teachers' designing effective and interactive learning environments, the use of education materials prepared in accordance with the principles of educational technology has a great importance. The 
new math curriculum has been designed with a conceptual approach based on the principle of "every child can learn math."

Children can express their thoughts with actual, imaginative and symbolic ways. The use of concrete materials such as physical objects allows them to express their thoughts through actual presentations. The importance of using materials in teaching is an undeniable truth. The use of training materials has been supported by many effectual theories in the field of education. Today, Mathematics has not been perceived as the collection of required abstract concepts and skills as in the past, but perceived as the knowledge that is based on the modeling of reality and formed by the process of problem solving and interpretation and also the developing skills in this process. The basis of this modeling is to use materials. There are also local studies emphasizing the importance of the use of materials in mathematics education. When the studies that reached successful results with the use of materials are analyzed, the relationship between the materials and symbolic presentations were seen to have been at the forefront. Inadequacies of the teachers in using and developing materials are among the factors pointed out in the researches. Teachers stated that the cause of the difficulties they encountered when using the material in mathematics teaching was the inability to display everything about the subject on the material and the inability to update the materials. In this context, the material should be considered primarily to address the whole issue, to be easy, understandable and interesting and in particular to be updated while designing. Geometry is an important learning field of mathematics and has an extensive coverage in elementary mathematics. The acquisitions of Transformation Geometry are as follows: setting back a shape to the right, left, up or down on a ruler or dotted paper with the desired rate, reflecting an object based on a straight line, rotating shapes around a point on a plane or based on a specified angle. Various dynamic geometry software programs such as Cabri Geometry, Geometer's Sketchpad, GeoGebra and Cinderella have been developed in order to be used in teaching geometry. The above-mentioned geometry software programs are also specifically used on the Transformation Geometry. The lack of a physical material to be used in teaching transformation geometry which supports students' creative thinking and three-dimensional thinking and is also associated with many math topics has drawn attention. The purpose of the study is to analyze the usability of "Transformation Wheel" material which will allow students to use individually, provide them to learn by experience and assist teachers in teaching Transformation Geometry. Additionally, determining of the students and teachers' views related to the developed material is another purpose of the study.

\section{Method}

The answer of the question of "Is "Transformation Wheel" material an effective and usable material in teaching the acquisitions described in the 7th grade mathematics curriculum about Transformation Geometry and in performing of applications related to the subject?" has been sought. The action research method was used in the study. In this research method, researchers use practical research techniques while solving 
problems they encountered during their applications. In the application stage of the study, Transformation Wheel was introduced to the students and the acquisition of the rotation move of the lower learning area in Transformation Geometry was presented to them accordance with the detected state. All applications related to the subject were performed by the material.Finally, the views of teachers and students related to the material were analyzed. The research was conducted with 217 th graders in a middle school located in Bagcilar district in Istanbul, Turkey and 9 math teachers working at the same school and different schools. 7 of the teachers had over 10 years of experiences in teaching, while 2 of them had 3 years experiences in teaching. In this research, two data collection tools including application questions and semi-structured forms were used. Application questions are the questions prepared for strengthening the topic after described with the help of the material. 5 questions selected by an expert opinion from MOE textbooks are in the application test. Semi-structured form is a form prepared for receiving the views of the teachers and students related to the transformation wheel material. The prepared form questions consist of these kinds of subjects: "Their views on the use of transformation wheel concrete material", "Difficulties in the use of transformation wheel concrete material" and finally "Their favorite features of transformation wheel concrete material". In the analysis of the obtained data, descriptive analysis approach was used. Therefore, a variety of categories for qualitative data was created and presented in a table after calculating their frequencies and percentages.

Transformation Wheel material is capable of rotating in both clockwise and counterclockwise with the intent of students' comprehending the acquisitions of the topic and ensuring the control of applications. Transformation Wheel aims to teach the students the core logic of rotation under the subject of Transformation Geometry and then to make them practice the topic with the exercises required active and practical participation. Transformation Wheel material is a two-sided single material, both of which can rotate separately, and consists of the sections of wide contents and applications.

\section{Result and Discussion}

In our research, the usability of Transformation Wheel material that is developed related to Transformation Geometry, which brings 3D thinking to forefront, was searched. The views of the teachers and students on the material were also analyzed separately. The majority of the students have found the material useful in learning or remembering the topic. They have also expressed that they did not experience any difficulties in using the material. Students additionally stated that with the help of the material, they learned and strengthened the topic better, and they benefited from it. The material also caused a change in their perspectives towards mathematics and they wanted to use the material later on. The students' finding the course which is taught using the material interesting indicates that Transformation Wheel material has already reached the desired goal. The majority of the teachers who participated in our research assessed the material as useful and usable. 
Similar to the results obtained in our research, Kutluca and Akin, in their study they conducted in 2013, have reached useful findings related to teachers and prospective teachers' using the material in mathematics courses. Our study can be reconducted under wider opportunities. For example, an individual Transformation Wheel can be provided for each student in a classroom environment, and students can be allowed to perform applications with the material. Besides, students can be given more opportunities to use the Transformation Wheel material further by keeping the working process longer. Based on this originally designed material, students can be encouraged to design their own materials.

\section{Gíriş}

Günümüz dünyasında, bireylerin bilgiyi tek bir kaynaktan almaları ve ezberlemeleri beklenmemekte, aksine bilgiye ulaşma yollarını bilen, bunları kullanabilen ve karşılaştı̆̆ı sorunlar karşısında bilgiyi kullanarak çözüm yöntemlerini oluşturabilen bireylerin yetiştirilmesi amaçlanmaktadır. Bireylerin bu özellikleri kazanmalarında ve öğretmenlerin etkin ve etkileşimli öğrenme ortamlarını tasarlamalarında, öğretim teknolojileri ilkelerine uygun olarak hazırlanmış eğitim materyallerinin kullanımı büyük önem taşımaktadır (Şahin ve Yıldırım,1999). Eğitim materyallerinin kullanımı, eğitim alanında geçerli pek çok teori tarafından desteklenmektedir (Buruner, 1966, 2006; Dienes ve Golding, 1971; Piaget, 1971; Skemp, 1987). Yeni Matematik öğretim programı kavramsal bir yaklaşımla ve "her çocuk matematiği öğrenebilir" ilkesine dayanılarak hazırlanmıştır. Bu ilke ve yaklaşımla hazırlanan yeni matematik programı, öğrenciyi ve öğrencinin ilgilerini, isteklerini, ihtiyaçlarını merkeze alarak öğrencinin zihinsel ve fiziksel olarak aktif olduğu bir eğitim ortamı oluşturmayı amaçlamıştır. Eğitim ortamında, öğrencinin problem çözme, iletişim kurma, akıl yürütme ve ilişkilendirme gibi farklı beceriler geliştirmesi hedeflenmiştir (MEB, 2009).

Batdal (2005) yeni uygulanan ilköğretim matematik öğretim programı ile daha önce uygulanmakta olan programı öğrenci odaklı bir yaklaşım ile irdelemek amaçlı yaptığı araştırmasında, yeni matematik öğretim programında kavrama ve uygulamaya yönelik, sürekli ve dinamik, öğretmen değil öğrenci merkezli, değişebilir ve güncel gibi özelliklerin dikkate alınarak değişiklikler yapıldığı ve matematiği zorlaştırmadan eğlenceli bir biçimde öğretmenin hedeflendiğini saptamıştır. Bruner'e $(1966,2006)$ göre çocuklar düşüncelerini eylemsel, imgesel ve sembolik yollarla ifade edebilirler. Fiziksel nesneler gibi somut materyallerin kullanımı, onların eylemsel gösterimler yoluyla düşüncelerini ifade etmelerine olanak sağlar. Öğretimde materyal kullanmanın önemi yadsınamaz bir gerçektir. "Schibeci, Lake, Lowe, Cummings ve Miller (2008), öğrenme nesnelerinin (öğretim materyallerinin) değerlendirilmesi üzerine yaptıkları çalışmalarında öğrenme nesnelerinin öğrencilerin motivasyonunu ve öğrenme için sergiledikleri çabayı arttırdığını; dolayısıyla başarılı bir öğrenme gerçekleştirildiğini belirtmişlerdir. Kay ve Knaack (2008)'ın çalışmalarından elde ettikleri bulgulara göre ise materyal kullanımının öğrenmeye olan pozitif etkisi konusunda öğretmenler 
öğrencilere kıyasla daha olumlu tutum sergilemektedir. Yani öğretmenler, matematik dersinde materyal kullanımının öğrenci performansında anlamlı bir artış sağladığını düşünmektedir. Öğrencilerdeki bu başarı artışına gerekçe olarak ta öğrencilerin materyal kullanıldığı zaman derse ilgilerinin artması ve materyallerin anlamayı kolaylaştırması gösterilmektedir. Materyal kullanımını destekleyen kuramsal alt yapıda bu görüşleri destekler niteliktedir" (Özdemir, 2008).

\section{Matematik Öğretimi ve Materyal}

Matematik günümüzde eskisi gibi, öğrenilmesi gerekli soyut kavramların ve becerilerin bir koleksiyonu değil, realitenin modellenmesini temel alan, problem çözme ve anlamlandırma süreci ile oluşan bilgi ve yine bu süreç içinde gelişen beceriler olarak algilanmaktadır (De Corte, 2004).Bu modellenmenin temeli ise materyaller kullanmaktır. Materyaller soyut matematik kavramlarını temsil etmek için tasarlanmış, öğrencilerin çeşitli duyularını harekete geçiren, görsel ve hareket ettirilebilen nesnelerdir (Moyer, 2001). Heinich (1996) tarafından öğretim materyali "bilginin öğrenene ulaştırılabileceği farklı yollar ve ortamlar" olarak tanımlamaktadır. Eğitim materyallerinin kullanımı, eğitim alanında geçerli pek çok teori tarafından desteklenmektedir (Buruner, 1966, 2006; Dienes ve Golding, 1971; Piaget, 1971; Skemp, 1987).

"Materyal kullanımı ile başarılı sonuçlara ulaşan çalışmalar incelendiğinde materyaller ile sembolik gösterimler arasındaki ilişkinin derslerde ön planda olduğu görülmektedir. Örneğin, Wearne ve Hibert (1988) ondalık kesirlerin öğretiminde, Dienes onluk taban blokları ve para gibi materyaller ile sembolik gösterimler arasındaki ilişkiyi vurgulamış ve öğrenciler ondalık kesirlerin çeşitli somut ve soyut gösterimlerini bir arada kullanmışlardır. Benzer şekilde Fuson ve Briar (1990) çok basamaklı sayılarla toplama ve çıkarma işleminin öğretiminde, onluk taban blokları ile yapılan eylemler ile sembolik gösterimle yapılan işlemleri ilişkilendirmiştir. Cramer ve meslektaşları (2002) ise dördüncü ve beşinci sınıf seviyelerinde kesirleri öğretmek için çoklu modeller (materyal, sembolik gösterim, gerçek-yaşam örnekleri vb.) kullanmış ve derslerde bu modellerinbirbirleriyle ilişkisi vurgulanmıştır" (Özdemir,2008, s.363 ).

Matematik öğretiminde materyal geliştirmenin önemine ve kullanımına dikkat çeken yerli araştırmalarda mevcuttur (Delice, Aydın ve Kardeş, 2009; İpek ve Baran, 2011; Bozkurt ve Akalın, 2010).

“Matematik öğretiminde materyal kullanımı maalesef diğer alanlara nazaran daha kısıtlıdır. Bu durumun pek çok bileşeni olabilir. Matematik öğretmenlerinin materyal geliştirme ve kullanmadaki yetersizlikleri araştırmalarda dikkat çeken unsurlar arasındadır (Odabaşı ve Gündüz,2004). Materyallerle matematik öğrenmenin etkili olabilmesi için, öğretmenlerin uygun materyalleri seçebilme ve bunları derslerinde etkili bir şekilde kullanabilme ve etkili materyal geliştirme becerilerine sahip olmaları gerekmektedir" (Özdemir, 2008, s.364 ).

Öğretmenler, matematik öğretiminde materyal kullanırken karşılaştıkları zorlukların nedenlerinden materyal üzerinde konuya ait her şeyin gösterilememesi ve 
materyallerin güncellenebilir olmamasını göstermişlerdir. Bu çerçevede materyal tasarlanırken öncelikle konunun bütününe hitap etmesi, kolay ve anlaşılabilir olması, ilgi çekici olması ve özellikle güncellenebilir olması göz önüne alınmalıdır (Aksüt, Bulut ve Yalvaç, 2010; Jan Gahala, 2005).

\section{Dönüşüm Geometrisi}

Geometri, matematiğin önemli bir öğrenme alanıdır ve ilköğretim matematiğinde önemli bir yer tutar. Geometri öğrenme alanında diğer alanlarda olduğu gibi önemli değişiklikler yapılmıştır. Geometri öğrenme alanında yeni olan alt öğrenme alanları; dönüşüm geometrisi, iz düşüm, örüntü ve süslemelerdir. Bu alt öğrenme alanlarına yeni giren kavramlar, öteleme, yansıma, dönme, örüntü, süsleme ve perspektiftir (MEB, 2009). Dönüşüm geometrisi için de öğrenciye bir şeklin cetvel veya noktalı kâğıt üzerinde sağa, sola, yukarı veya aşağıya istenilen oranda ötelenmesi, bir cismin bir doğruya göre yansıması, düzlemde bir nokta etrafında ve belirtilen bir açıya göre şekillerin döndürülmesi yer almaktadır. Örüntü ve süslemeler alt öğrenme alanında, öğrencilere eş çokgensel bölgeleri kullanarak genişleyen örüntü modelleri inşa ettirilmekte, kâğıt kesme, katlama ve yapıştırma etkinlikleri ile süsleme çalışması yaptırılmaktadır.

Geometrik cisimler alt öğrenme alanında eski programdan farklı olarak eş küplerle oluşturulmuş yapıların farklı yönlerden görünümleri noktalı veya kareli kağıtt üzerine çizdirilmekte; farklı yönlerden görünümlerine ait çizimleri verilen yapılar, birim küplerle oluşturulmakta ve izometrik kağıda çizdirilerek öğrencilerin uzamsal düşünme yetenekleri geliştirilmeye çalışılmaktadır. $\mathrm{Bu}$ konuların programda bulunmasının amacı ortaöğretimdeki bazı konuların alt yapısını oluşturmaktır. Örneğin, öteleme konusu ortaöğretimde fonksiyon konusunun, dönme konusu trigonometrinin anlaşılması için gereklidir. Özellikle iköğretim çağındaki öğrencilerin geometri ile ilgili kazanımları gerek günlük yaşamlarında gerekse ileriki yıllardaki çalışma alanlarında önemli rol oynar. (Gürbüz ve Durmuş, 2009).

“Geometri öğretiminde kullanılmak üzere Cabri Geometry, Geometer's Skechpad, GeoGebra ve Cinderella gibi çeşitli dinamik geometri yazılımları geliştirilmiştir. Bu programlarda çizim yapılırken çeşitli geometrik şekil ve cisimlerin farklı türden özelliklerine ait ölçümler yapılabilmekte ayrıca analitik geometriye ilişkin bilgiler program tarafından sağlanabilmektedir. Bu programların yapılandırmacı felsefeye uygun öğretim için faydalarına işaret eden çok sayıda çalışmaya rastlamak mümkündür (Carter ve Ferrucci, 2009; Gündüz, Emlek ve Bozkurt, 2008; Güven, 2002; Güven ve Karataş, 2003; Hohenwarter ve Fuchs, 2004; Hohenwarter, Jarvis ve Lavicza, 2009; Kabaca, Çontay ve İymen, 2011; Kokol-Voljc, 2007; Konyalığlu ve Işık, 2005; Kösa ve Karakuş, 2010) (Aktaran: Ural,2014, s. 94).

Yukarıda adı geçen geometri yazılımları, dönüşüm geometrisi konusunda da özel olarak kullanılmaktadır. Bahsi geçen yazılımlar kullanılarak yapılan mevcut çalışmalar konunun anlatımının ve anlaşılmasının kolaylaştırılması, anlatımın zenginleştirilmesi gibi amaçlar doğrultusunda gerçekleştirilmiştir. 


\section{Çalışmanın Amacı}

Alan yazın incelendiğinde, dönüşüm geometrisi ile ilgili yapılan çalışmaların öğretmenlerin ve öğretmen adaylarının bu konudaki ve konuyu öğretmedeki yeterliliklerinin yanında dinamik geometri yazılımları kullanımları üzerine yoğunlaşmakta olduğu görülmektedir (Güven ve Yılmaz, 2012; Gürbüz ve Durmuş, 2009). Öğrencilerin yaratıcı düşünmesini ve üç boyutlu düşünmeyi destekleyen ayrıca pek çok matematik konusuyla ilişkili olan dönüşüm geometrisi konusunun öğretilmesinde kullanılacak fiziksel bir materyalin eksikliği dikkat çekmektedir. Öğrencilerin bizzat kullanabilecekleri, yaparak yaşayarak öğrenmelerini sağlayacak ve dönüşüm geometrisi öğretiminde öğretmenlere yardımcı olacak "Dönüşüm Çarkı" materyalinin kullanılabilirliğinin incelenmesi ve geliştirilen materyalle ilgili öğretmen ve öğrenci görüşlerinin belirlenmesi çalışmanın amacıdır.

Dönüşüm Çarkı materyalinin 7. Sınıf müfredatında bulunan Dönüşüm Geometrisi konusunun kazanımlarından biri olan 'Dönme hareketi' kazanımının öğrencilere kazandırılmasında etkili bir materyal olup olmadığını saptamak bu çalışmanın temel amacıdır. Dönüşüm Çarkı materyali kullanılarak öğrencilerin etkili bir öğrenme gerçekleştirmesini sağlamak, matematik dersinde, öğrencilerin derse ilgisini arrtıracak görsel materyaller kullanmaktır.

$\mathrm{Bu}$ amaçlar çerçevesinde 7.sınıf müfredatında yer alan Dönüşüm Geometrisi konusunun kazanımlarının "Dönüşüm Çarkı" materyali ile desteklenmesi amaçlanmıştır.

“Dönüşüm Çarkı" materyali 7. sınıf matematik dersi müfredatında bulunan dönüşüm geometrisi konusunda belirlenen kazanımların öğrencilere anlatılmasında ve konuyla ilgili uygulamaların yapılmasında kullanılabilir ve etkili bir materyal midir? Sorusuna cevap aranacaktır.

\section{YÖNTEM}

Çalışmada aksiyon araştırması yöntemi kullanılmıştır. Aksiyon araştırması, herhangi bir olgu, olay ya da subjeyi içinde gerçekleştirdiği ya da bulunduğu sosyal bir durumda sistematik olarak tanımak ve geliştirmek amacıyla sosyal durum içindeki kişi ya da kişiler tarafından yürütülen bilimsel bir etkinliktir. Aksiyon araştırması yöntemi öğretmenlerin kendi uygulamalarının doğası hakkında daha derinlemesine bir görüş ve anlayış kazanmalarını amaçlamaktadır. Bu araştırma yönteminde araştırmacı öğretmenler uygulamaları süresince karşılaştıkları problemleri çözerken pratik araştırma teknikleri kullanmaktadırlar. (Çepni, 2010)

Çalışmanın amacı çerçevesinde 7.sınıf müfredatında yer alan Dönüşüm Geometrisi konusunun kazanımlarının öğrencilere kazandırmayı hedefleyen Dönüşüm Çarkı materyalinin derste uygulama yöntemi şu şekildedir;

1. Dönme hareketini açıklar.

A. Döndürülen şeklin cisim ve boyutunun değişmediği, ancak şeklin duruşunun ve yerinin değiştiği görülür. 
B.Dönme hareketi ve dönmenin sırasıyla, çember çizme ve çemberin çizim yönü ile ilişkilendirilir.

2. Düzlemde bir nokta etrafında ve belirtilen bir açıya göre şekilleri döndürerek çizimini yapar.

A. Çeyrek dönmenin $90^{\circ}$ (derece)'lik dönme, yarım dönmenin $180^{\circ}$ (derece)'lik dönme olduğu görülür.

B.180 (derece)' lik dönmenin merkezil dönme(noktaya göre simetri) olduğu görülür.

“Dönüşüm Çarkı" materyali 7. sınıf matematik dersi müfredatında bulunan dönüşüm geometrisi konusunda belirlenen kazanımların öğrencilere anlatılmasında ve konuyla ilgili uygulamaların yapılmasında kullanılabilir ve etkili bir materyal midir? Sorusuna cevap aranacaktır.

\section{Dönüşüm Çarkı Materyali}

Dönüşüm Çarkı materyali; konunun kazanımlarının öğrencilere kavratılması ve yapılan uygulamaların kontrolünü sağlamak amacıyla saat yönünde ve saat yönünün tersinde dönme hareketi yapabilmektedir. Dönüşüm Çarkı, öğrencilere Dönüşüm Geometrisi konusundaki dönme hareketinin temel mantığını öğretmeyi, sonrasında ise pratik ve aktif katılımlı alıştırmalarla tekrar yaptırmayı hedef almıştır. Dönüşüm çarkı materyali konu anlatımı ve uygulama bölümleri olmak üzere iki yüzüde ayrı dönebilen tek parçadan oluşan bir materyaldir.
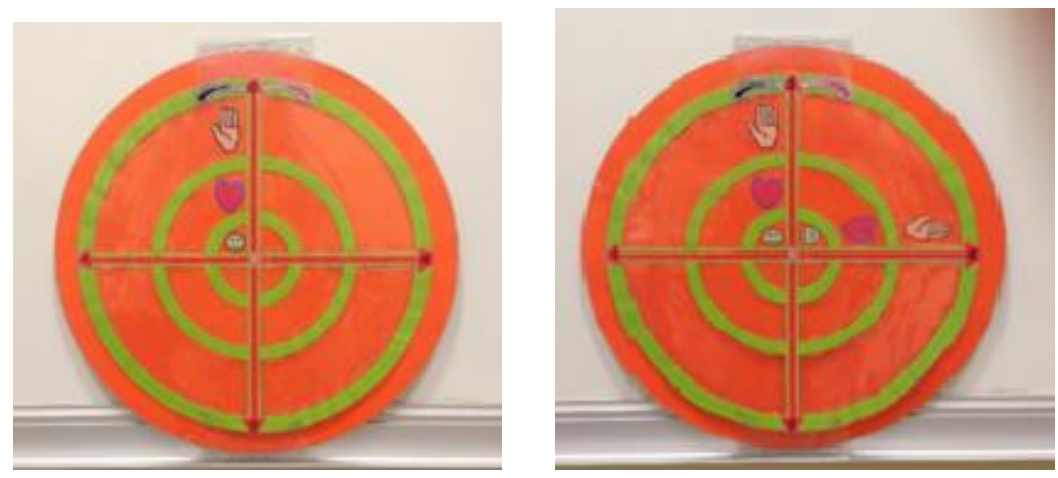

Resim1-2. Konu anlatım tarafi
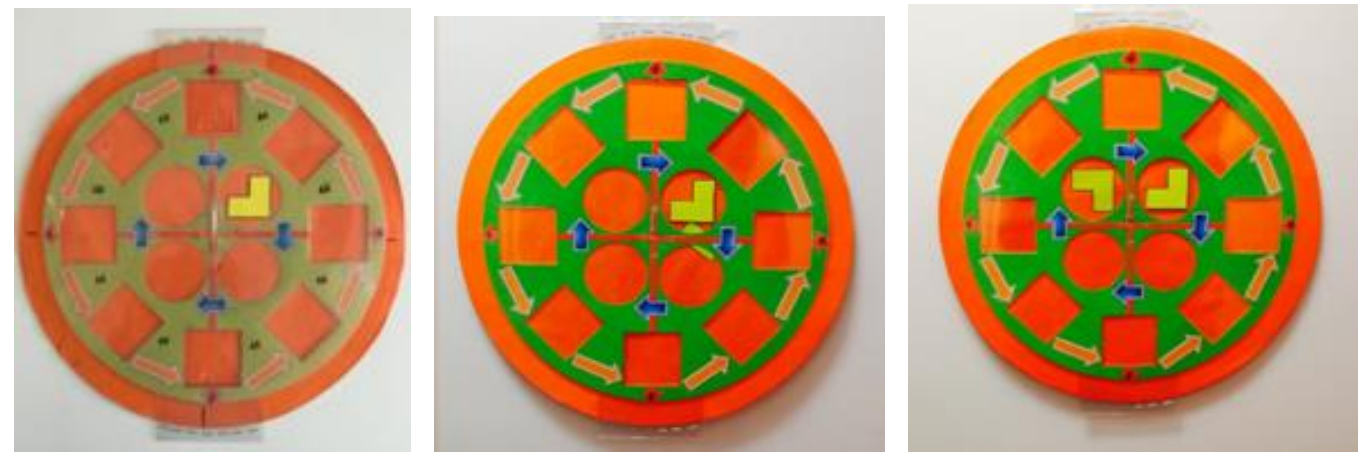

Resim3-4-5. Uygulama tarafi 
Dönüşüm Geometrisi konusunun anlatımı sırasında öğretmen Dönüşüm Çarkı'nın hareketli sistemi sayesinde, materyalin konu anlatımı tarafında dönme hareketini göstererek öğrencilerden konunun kazanımlarını veya dönme hareketinin özelliklerini bulmalarını isteyebilir. Bu etkinlik sayesinde öğretmen öğrencilere rehberlik etmiş olup, öğrencilerin öğrenmelerini buluş yoluyla gerçekleştirmeleri sağlanacaktır. Konunun kazanımları verildikten sonra öğretmen, Dönüşüm Çarkı'nın uygulama tarafındaki çalışma çemberleri sayesinde öğrencilere konuya yönelik alıştırmalar yaptırarak, öğrencilerin konuyu pekiştirmesini sağlayabilir. Bu alıştırmalar sırasında öğretmen, öğrencilerini gözlemleyerek öğrenme düzeylerini de ölçebilir.

Tasarladığımız matematik materyali; uzun ömürlü olması ve istenilen sayıda alıştırma yapma imkânı sunabilmesi için PVC kaplama ile kaplanmıştır. Bu sayede öğrenciler uygulama çemberlerini yazı tahtası gibi defalarca kullanabileceklerdir. Ayrıca materyalin görüntüsün renkli ve ebatlarının da çok büyük olmaması, öğrenciyi materyali kullanmaya teşvik edecek ve istediği yerde kolaylıkla kullanabilme imkânını sağlayacaktır.

Dönüşüm Çarkı;

$\checkmark$ Konu anlatım tarafı ile "bilgiyi sunma"

$\checkmark$ Renkli ve ilginç tasarımı ile öğrencide merak uyandırarak "dikkat çekme"

$\checkmark$ Uygulama tarafı ile"aktif katılımı sağlama"

$\checkmark$ Hareketli kontrol sistemi ile" dönüt sağlama

$\checkmark$ Hareketli kontrol sistemi ile"düzeltme"

$\checkmark$ Sabit çalışma çemberi ile "ipucu verme"

$\checkmark$ Serbest çalışma çemberi ile"alıştırma yapma"

$\checkmark$ Serbest çalışma çemberi ile "tekrar yaptırma" imkânı sunabilmektedir.

\section{Materyal ile Bir Uygulama}

Materyal iki yüzden oluşmaktadır: Ön yüz -konu anlatım tarafı (şekil 7.) ve arka yüz-uygulama tarafı (Şekil 8.). Derse giren öğretmen, öğrencilere dönme deyince akıllarına neler geldiğini sorar. Bu sayede öğrencilerin konu ile ilgili hazır bulunuşluklarını ölçmüş olur.

Öğretmen materyalin ön yüzünü, dönme hareketinin ne olduğunu ve özelliklerini öğrencilere kazandırmak için kullanır. Öğretmen çarkı 90 derece saat yönünde ( Şekil 9) döndürür ve öğrencilere cisimlerin ilk duruşları ile döndürülmüş durumları arasında ne gibi benzerlik ve farklılıklar olduğunu sorar. Öğrencilerden dönme hareketi ile cisimlerinin şekil, boyut ve renk gibi özelliklerinin değişmediğini, sadece yön ve duruşlarının değiştiği cevabını almayı hedefler. Aynı mişlemi 180, 270 ve 360 dereceleri için saat yönünde ve saat yönünün tersinde yapar. 


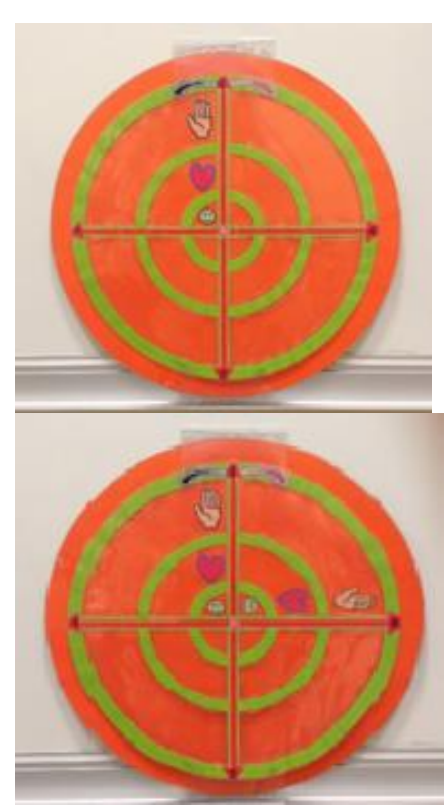

Şekil 7.

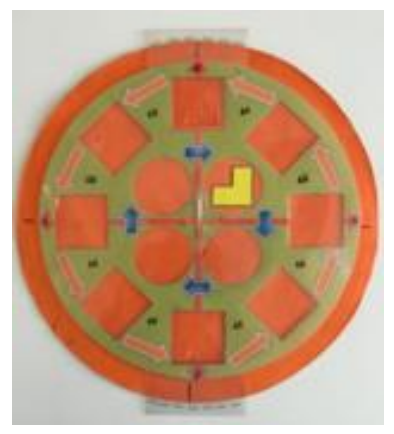

Şekil 8.

Şekil 9.

Sonrasında çarkı tam tur-360 derece döndürür ve bu dönüş ile döndürülen cisimler tekrar ilk duruşlarına gelirler. Bu uygulama ile öğrencilerden tam tur-360 derece dönmenin cisimlerin ilk duruşlarına geri dönecekleri cevabını almak ister. Öğretmen aynı işlemi yarım tur- 180 derece için de yapar ve bu durumda da cisimlerin ilk durumları ile son durumlarının tam tersi yöne baktığı cevabını almak ister. Öğrencilerden almayı hedeflediği cevaplara yönlendirmeleri ve dönüşüm çarkı materyali ile ulaşan öğretmen dönme hareketini ve özelliklerini öğrencilere kazandırmış olur. Konu anlatımından sonra uygulama ve örnek çözümü için materyalin arka yüzünü-uygulama tarafını kullanır. Materyalin arka yüzü- uygulama tarafı iki ayrı çalışma çemberi ile öğrencilere örnek çözme ve uygulama yapma imkanı sunmaktadır. Bunlar, sabit çalışma çemberi ve serbest çalışma çemberidir.

Dönme hareketi konusunda örnek uygulama yapmak isteyen öğretmen materyalin arka yüzünü kulanır. Önce sabit çalışma çemberine yerleştirilmiş olan ' L' şeklindeki cisminin dönme uygulamasını öğrencilere yaptırır. L şeklin saat yönünde 90 derece döndürüldüğünde oluşan şekil öğrencilere sorar Dönme işlemi sonucunda yeni şeklin hangi yuvarlak boşlukta olacağını da sorarak doğru yere doğru şeilde çizmelerini ister (Şekil 10.). Döndürme işlemi yapılır ve çarkın turuncu kısmı döndürürlür. Sarı L şeklinin altında, turuncu karton kısmında bir sarı L şekli daha bulunmaktadır ve döndürme işlemi yapılırken yani turuncu karton döndürülürken üzerindeki sarı L şekli de döner. Öğrenci eğer doğru boşluğa doğru şekli çizerse öğretmen çarkı döndürdügünde öğrencinin çizdiği şekil ile materyalin turuncu kartonu ile döndürülmüş olan L şekli yani başlangıçtaki şeklimizin 90 derece saat yönünde döndürülmüş yeni yeni görüntürü üst üste gelmelidir (Şekil 12). Bu esnada çizimden kaynaklanan ufak farklılıklar olabilir, önemli olan iki şeklin çizildiği boşluğun ve duruşlarının örtüşmesidir. 


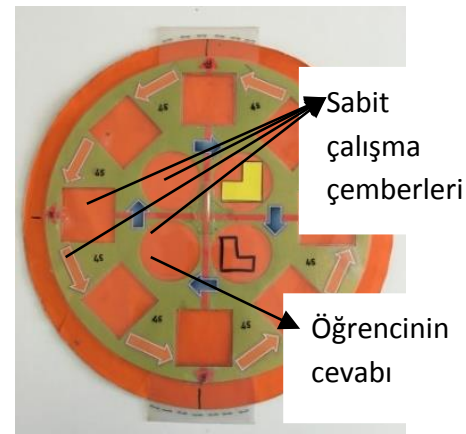

Şekil 10.

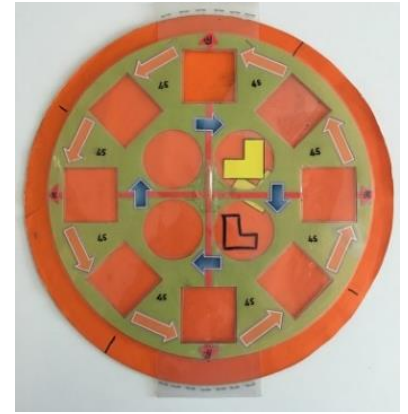

Şekil 11.

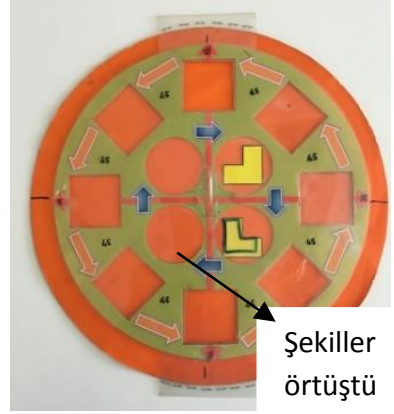

Şekil 12.

Ĕ̆er öğrenci yanlış boşluğa çizim yaparsa ya da yanlış duruşta şekil çizerse (Şekil 13.), çark döndürüldügünde şekiller örtüşmez (Şekil 15.) ve öğrenci yanlış yaptığını görür. Çarkın döndürülmesi sayesinde doğru şeklin hangi boşlukta ve duruşta çizilmesi gerektiğini doğru şekilde görür. Bu uygulama ile öğrenci hem sonucunun doğru mu yanlış mı olduğunu kontrol eder hem de yanlışının cevabını almış olur.

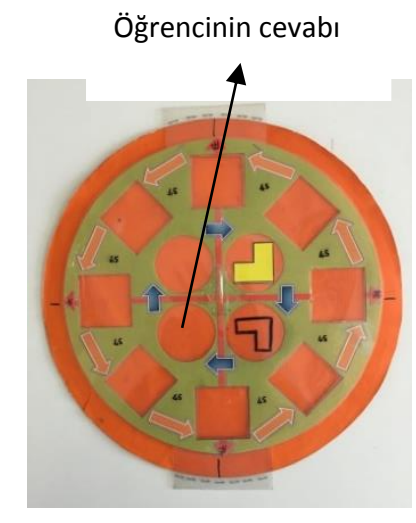

Şekil 13.

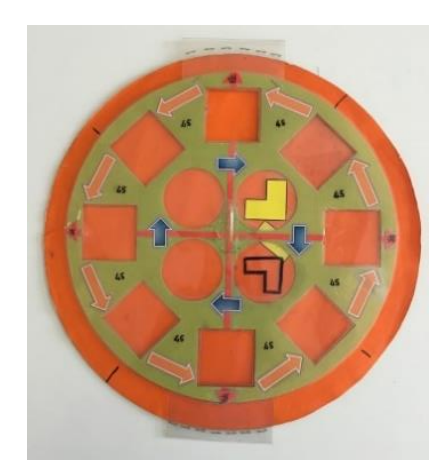

Şekil 14.

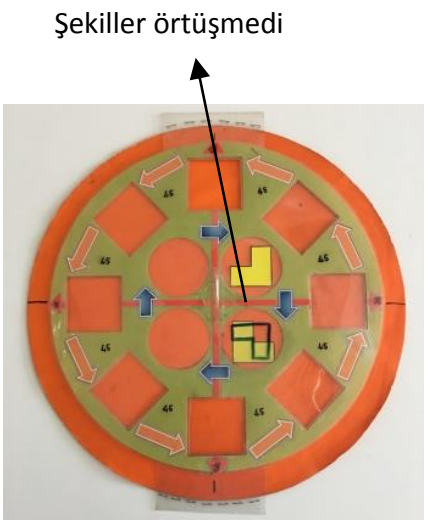

Şekil 15.

Sabit çalışma çemberi ile mevcut örnek döndürme uygulamasını yaptıran öğretmen, daha sonra serbest çalışma çemberinde en üstte bulunan boş kareye istediği örnek cismi çizerek öğrencilerin 45, 90, 135, 180, 225, 270, 315 ve 360 derece saat yönünde ve saat yönünün tersinde döndürme alıştırmalarını öğrencilerine yapıtırabilir. Mesela öğretmen sağ ayağında yatay bir çizgi olan ters A harfi çizsin (Şekil 16.) Öğrencilerden bu şeklin saat yönünde 45 derece döndürülmüş halini doğru kare boşluğu seçerek çizmelerini istesin. Öğrenciler, öğretmeninin çizdiği cismin döndürülmüş halini seçtikleri kare boşluğa çizsin ( Şekil 17.). Öğretmen, öğrenciler çizimlerini yaptıktan sonra yine turuncu kartondan tutarak çarkı istediği açıda ve yönde döndürdüğünde çizmiş olduğu şeklin döndürülmüş halini materyal öğrencilere gösterecektir. Bu sayede öğrenciler cevaplarını kontrol edebilir. Eğer öğrenciler doğru çizim yaptılarsa dönrülen şekil ile kendi çizimleri üst üste gelerek örtüşecektir( Bu örtüşme çizim farklılıkları sebebi ile tam olarak üst üste gelmeyebilir. Önemli olan doğru yönde ve doğru boşluğa çizilmiş olmasıdır.), (Şekil 18.). 


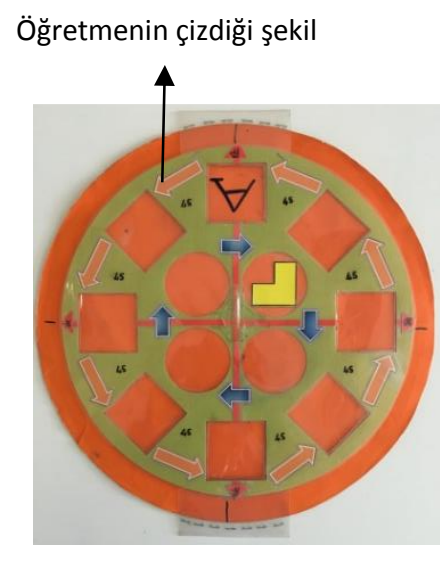

Şekil 16.

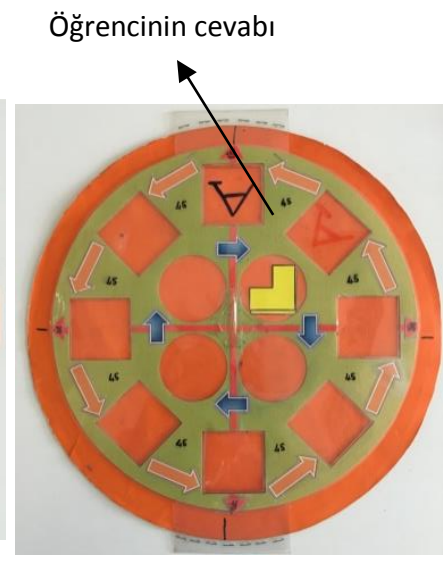

Şekil 17.

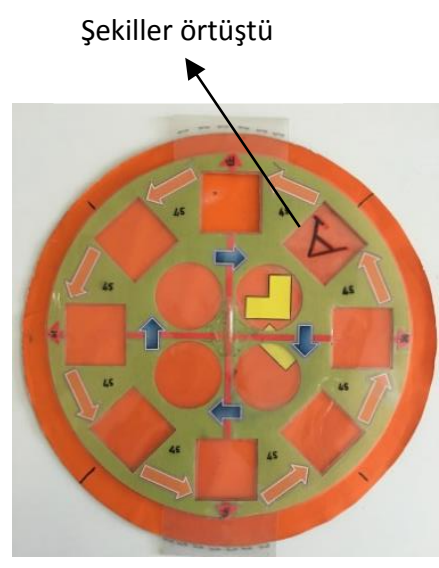

Şekil 18.

Öğrenciler yanlış çizim yaptıklarında (Şekil 19.), çark döndürüldüğünde öğrenciin çizimi ile öğretmenin çiziminin döndürülmüş hali örtüşmeyecektir (Şekil 20.). Bu sayede öğrenciler hem cevabının yanlış olduğunu anlayacak hem de doğru döndürülmüş hali görmüş olacaktır.

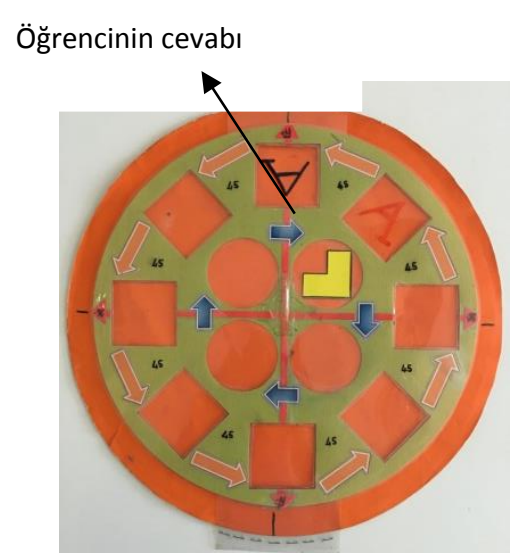

Şekil 19.

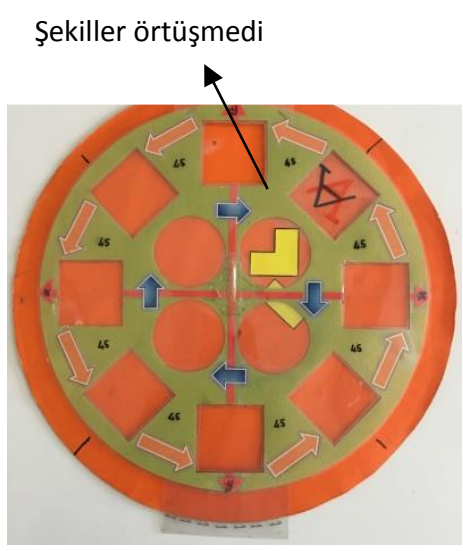

Şekil 20.

\section{Araştırma Grubu}

Araştırma, İstanbul Bağcılarda bulunan bir ortaokulun 7. Sınıfında bulunan 21 öğrencinin yanı sıra uygulamanın yapıldığ 1 okul ve farklı okullardaki 9 matematik öğretmeni ile yapılmıştır. Öğretmenlerden 7 tanesi 10 yıl ve üzeri öğretmenlik tecrübesine sahipken 2 tanesi 3 ylllık öğretmenlik tecrübesine sahiptir.

\section{Verilerin toplanması ve analizi}

$\mathrm{Bu}$ araştırmada, uygulama soruları ve yarı yapılandırılmış form olmak üzere iki veri toplama aracı kullanılmıştır. 
Uygulama Soruları: Konu materyal yardımı ile anlatıldıktan sonra konunun pekiştirilmesine yönelik uygulama sorularıdır. MEB kitaplarından uzman görüşü ile seçilen 5 soru uygulama testinde bulunmaktadır. Sorulardan iki tanesi aşağıda verilmiştir.
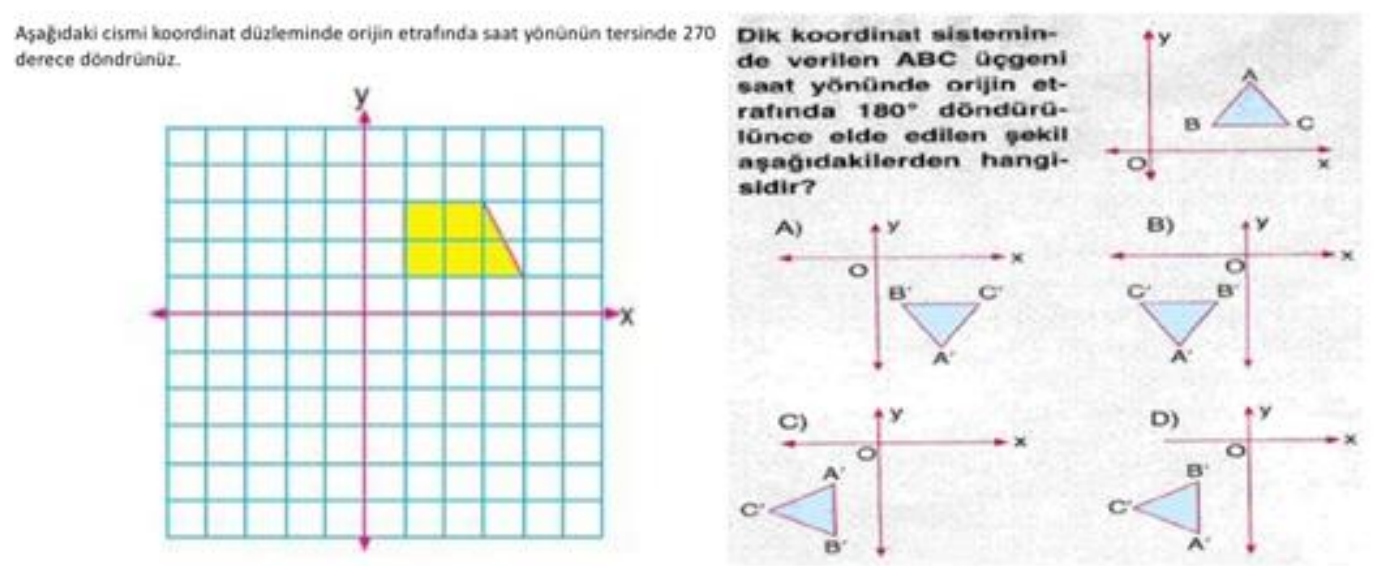

Şekil 1-2. Uygulama soruları

\section{Yarı Yapılandırılmış Form}

Öğrencilere ve öğretmenlere sunulan ve uygulama imkânı verilen Dönüşüm Çarkı materyaline ilişkin öğrenci ve öğretmen görüşlerini almak için hazırlanan yarı yapılandırılmış form kullanılmıştır.

\section{Verilerin Analizi}

Elde edilen verilerin analizinde betimsel analiz yaklaşımı kullanılmıştır. Bu nedenle nitel veriler için çeşitli kategoriler oluşturmuş frekans ve yüzde hesabı yapılarak tablo hâlinde sunulmuştur. Bu kapsamda elde edilen veriler incelenerek araştırma amacı doğrultusunda kategoriler oluşturulmuş ve görüşlere ait bazı örnekler alıntılar yapılarak sunulmuştur.

\section{Uygulama}

Öncelikle örneklem grubundaki öğrencilerle tanışmak için bir görüşme yapılmıştır. Bu görüşmede öğrenciler ve araştırmacılar ismen tanışarak, yapılacak uygulamadan ve Dönüşüm Çarkı materyalinden bahsedilmiş ve materyal tanıtılmıştır. Materyalin ne amaçla tasarlandığı, onlara hangi konuda yardımcı olacağı öğrencilere anlatılmıştır. Materyalin genel tanıtımı yapıldıktan sonra materyal kullanılarak konu anlatımı gerçekleştirilmiştir. Sınıfta dönme hareketi dönüşüm çarkı materyali yardımı ile anlatılmış ve anlatım sonunda anlaşılmayan bir yer olup olmadığı sorulmuştur. Konu anlatımı sırasında kullanılan Dönüşüm Çarkı öğrencilerden oldukça fazla ilgi görmüştür. Ardından araştırmacı tarafından materyal üzerinde dönme hareketi ile ilgili uygulamalar yapılarak materyalin uygulama tarafı aktif olarak öğrencilere gösterilmiştir. Araştırmacının uygulamaları sayesinde materyal üzerinde nasıl alıştırma yapacağını görmüş olan öğrencilere dönme hareketi ile ilgili sorular 
yöneltilerek, öğrencilerin materyal üzerinde uygulama yapması sağlanmıştır. Her öğrenciye materyal üzerinde uygulama yaptırıldıktan sonra, öğrencilerin materyal ile ilgili görüş ve düşüncelerini almak için öğrencilere yarı yapılandırılmış form uygulanmıştır. 9 matematik öğretmenine de materyal tanıtılmış ve öğretmenlerin materyal hakkındaki görüşleri yazılı olarak alınmıştır.

\section{BULGULAR VE YORUMLAR}

$\mathrm{Bu}$ bölümde öğrencilerin ve öğretmenlerin Dönüşüm Çarkı somut materyali ile ilgili görüşlerinden elde edilen nitel veriler sunulmuştur.

\section{Dönüşüm Çarkı Somut Materyalinin Kullanımına İlişkin Öğrenci Görüşleri}

Tablo 1: Öğrencilerin "Bu materyal konuyu öğrenmenizde/hatırlamanızda faydalı oldu mu?" sorusuna verdikleri cevaplarm dağılımı

\begin{tabular}{ll}
\hline Değişkenler & $\mathbf{f}$ \\
\hline Evet & 20 \\
Hayır & 1 \\
\hline
\end{tabular}

Tablo1'de görüldüğü gibi araştırmaya katılan öğrencilerden \%95i Dönüşüm Çarkı materyalinin konunun öğreniminde veya hatırlanmasında faydalı olduğunu belirtmiş, \%5'i ise Dönüşüm Çarkı materyalinin konunun öğrenimine veya hatırlanmasına faydası olmayacağını belirtmiştir.

Tablo 2: Öğrencilerin "Materyalin en beğendiğiniz kısmı/kısımları nedir/nelerdir?" sorusuna verdikleri cevapların dağılımı

\begin{tabular}{ll}
\hline Değişkenler & f \\
\hline Konu anlatım tarafı(dönmeyi göstermesi) & 4 \\
Uygulama tarafı & 6 \\
Kontrol sağlaması & 9 \\
Kullanım şekli & 7 \\
Açıklık/ Anlaşılırlık & 2 \\
\hline
\end{tabular}

Tablo2' de görülen sonuçlar öğrenci sayısı ile eş olmamakla beraber, araştırmaya katılan her öğrenci Soru2'ye bir veya birden fazla cevap vermiş olup cevap vermeyen öğrenci bulunmamaktadır.Tablo2'de görülen sonuçlara göre Dönüşüm Çarkı 
materyalinin, yapılan örneklerin kontrolünü sağlama özelliği \%32,4 oranı ile en beğenilen özelliği olmuştur. Dönüşüm Çarkı materyalinin; kullanım şekli \%25,2, uygulama tarafı \%21,6, konu anlatım tarafı $\% 14,4$ ve açıklık/anlaşılırlık $\% 7,2$ oranında beğenildiği görülmektedir.

Tablo 3: Öğrencilerin "Materyalde zorlandığınız/anlayamadığınız kısım/kısımlar var mı? Varsa belirtiniz."sorusuna verdikleri cevapların dağılımı

\begin{tabular}{ll}
\hline Değişkenler & f \\
\hline Yok & 20 \\
$\begin{array}{l}\text { Saat yönünde ve tersinde dönmeyi } \\
\text { anlamakta zorlandım. }\end{array}$ & 1 \\
\hline
\end{tabular}

Tablo3'de belirtilen verilere göre araştırmaya katılan öğrencilerin \%95'i Dönüşüm Çarkı materyalinin kullanımında her hangi bir zorluk yaşamamış olup, \%5'i dönme hareketinin yapıldığı yönlerde karışıklık yaşamıştır. Fakat verilen cevaba göre zorluk yaşayan \%5'in, uygulamalar esnasında problemi çözdüğü belirtilmiştir.Soru3'ten elde edilen bulgulara göre, Dönüşüm Çarkı materyalinin aynı zamanda kullanım esnasında da öğrenmeyi pekiştirdiği sonucuna ulaşılmaktadır.

Tablo 4: Öğrencilerin "Materyalle öğrendiğiniz/tekrar ettiğiniz bu konuyu daha iyi öğrendiğinizi/pekiştirdiğinizi düşünüyor musunuz?" sorusuna verdikleri cevapların dağıllımı

\begin{tabular}{ll}
\hline Değişkenler & f \\
\hline Evet & 20 \\
Hayır & 1 \\
\hline
\end{tabular}

Tablo4'te belirtilen bulgulara göre araştırmaya katılan öğrencilerden $\% 95$ ' $\mathrm{i}$ Dönüşüm Çarkı materyali ile konuyu daha iyi öğrendiğini veya pekiştirdiğini ifade etmişken, \%5'i ise Dönüşüm Çarkı materyalinin mevcut konunun öğrenimi veya pekiştirilmesine fayda sağlamadığını ifade etmiştir.

"Bu materyalin size faydalı olduğunu düşündüğünüz yönleri nelerdir?" sorusuna öğrencilerin verdiği cevaplar aşağıdaki gibidir.

"Şekillerin yönleri değiştiğinde nasıl duracă̆ını gösterdi."

"Bazen yapamadı̆̆ım kısımlarda uygulamalı olarak öğretiyor."

"Uygulama yeri"

"Şekillerin farklı olduğu hallerini öğretti."

“Dönüş konusunda daha hızlı öğrenmemizi să̆lar." 
"Açıları ayarlamamda yardımoı oldu."

"Yanlışı anlamamızı să̆laması"

"Bir ekli kafa yormadan döndürmemiz faydalıydr."

"Şekil doğru mu?" diye arada kalmayacă̆ım."

"Basitçe kullanılabilmesi."

"Bütün yerleri."

"Uygulama tarafi."

"Hepsi çok faydalıdı."

"Daha iyi pekiştirdim."

"Yok."

"Bence materyal benim zekamı güçlendirdi."

"Bence çŏ̆u yeri faydal.."

"Cisimlerin belli bir açıyla çevrildiğindeki şekillerini daha hızlı hesaplamama yardımoı oldu."

"Şekillerle ve açılar şeklinde göstermesi."

"Döndüğ̈̈ için bana kolaylık sağladı."

Araştırmaya katılan 20 öğrenci Soru5'te Dönüşüm Çarkı materyalinin kendilerine faydasını birer cümle ile ifade etmiş olup, 1 öğrenci ise Dönüşüm Çarkı materyalinin kendisine faydalı olmadığını ifade etmiştir.Yani yukarıda verilen bulgulara göre araştırmaya katılan öğrencilerden \%95'i Dönüşüm Çarkı materyalinin kendilerine faydalı olduğu yönünde cevap vermiş olup, \%5'i Dönüşüm Çarkı materyalinin kendisine faydası olmadığını belirtmiştir.

"Bu materyal size matematiksel olarak ne kazandırdı?" sorusuna öğrencilerin verdiği cevaplar aşağıdaki gibidir.

"Bazı şekiller döndüğ̈̈nde nasıl görüneceğini öğretti”

"Açıları doğru şekilde yorumlamamı să̆ladı."

"Dereceleri."

"Şekillerin başka hallerinin nasıl çizildiğini öğretti."

"Şekillerin dönük hallerini düşünmemi kolaylaştırdı."

"Açı bilgimi genişletti"

"Boyunun, şeklinin değişmediğini kazandırdı. Dönmeyi anlamadır."

"Konuyu pekiştirmemi sağladı."

"Zihnimi kullanmama yardımcı oldu. Dönme hareketini anladım." 
"Şeklin doğruluğundan emin olacağım."

"Dönme hareketini kağıt üzerinde rahatça yapıyorum."

"Bana dönmüş cisimlerin yönlerini, duruşunu gösterdi."

"Dönme hareketini anlamama yardımcı oldu."

"Şekillerin dönmüş halini."

"Daha iyi öğrendim."

"Hiç bir şey."

"Açılar, yer değiştirme ve hareket etme."

"Öğrendiklerimi tekrarlamış oldum."

"Daha önce öğrendiğim matematik konusunu pekiştirmeme yardımcı oldu."

"Simetri ve geometri gibi konularda bana kolayca yardımcı oldu."

“Yanlış yaptığım matematik sorularına 'doğru mu?', 'yanlış mı?' diye bakabilirim.

Araştırmaya katılan 20 öğrenci Soru6'da Dönüşüm Çarkı materyalinin kendilerine kazandırmış olduğu matematiksel kazanımları özgün cümleler ile ifade etmiş olup, 1 öğrenci ise Dönüşüm Çarkı materyalinin kendisine matematiksel anlamda kazandırdığı hiç bir şey olmadığını ifade etmiştir. Yani yukarıda verilen bulgulara göre araştırmaya katılan öğrencilerden \%95'i Dönüşüm Çarkı materyalinin kendilerine matematiksel açıdan faydalı olduğu yönünde cevap vermiş olup, \%5'i Dönüşüm Çarkı materyalinin kendisine hiçbir matematiksel faydası olmadığını belirtmiştir.

Tablo 5: Öğrencilerin "Bu materyal matematiğe bakış açınızda değişikliğe sebep oldu mu?" sorusuna verdikleri cevapların dağılımı

\begin{tabular}{ll}
\hline Değişkenler & $\mathrm{f}$ \\
\hline Evet & 6 \\
Hayır & 15 \\
\hline
\end{tabular}

Tablo5'te görüldüğü gibi araştırmaya katılan öğrencilerin \%28,8'i Dönüşüm Çark1 materyalinin matematiğe bakış açısında değişikliğe sebep olduğunu düşünürken, \%72,2'si Dönüşüm Çarkı materyalinin matematiğe bakış açısında değişiklik sağmadığını belirtmiştir.

Tablo 6 Öğrencilerin "Bu tarz bir materyali daha önce kullandını mı?" sorusuna verdikleri cevapların dağılımı

\begin{tabular}{ll}
\hline Değişkenler & $\mathrm{f}$ \\
\hline Evet & 2 \\
Hayır & 19 \\
\hline
\end{tabular}


Tablo 6'da görüldügü gibi araştırmaya katılan öğrencilerden \%90,4' ü daha önce Dönüşüm Çarkı tarzında bir materyali kullanmadı̆̆ını belirtmişken, \%9,6'sı daha önce Dönüşüm Çarkı materyaline benzer bir materyal kullandığını ifade etmiştir.

Tablo 7: Öğrencilerin "Bu tarz bir materyali daha sonra kullanmak ister misiniz?" sorusuna verdikleri cevapların dağılımı

\begin{tabular}{ll}
\hline Değişkenler & $\mathrm{f}$ \\
\hline Evet & 2 \\
Hayır & 19 \\
\hline
\end{tabular}

Tablo7'de görüldüğü gibi araştırmaya katılan öğrencilerin \%100'ü (tamamı) Dönüşüm Çarkı tarzında bir materyali daha sonra da kullanmak isteğini belirtmiş olup, Dönüşüm Çarkı benzeri bir materyali daha sonra kullanmak istemeyen öğrenci bulunmamaktadır.

Tablo 8: Öğrencilerin "Diğer derslerde de bu tarz uygulamaların yapılmasını ister misiniz?" sorusuna verdikleri cevapların dağılımı

\begin{tabular}{ll}
\hline Değişkenler & $\mathrm{f}$ \\
\hline Evet & 18 \\
Hayır & 3 \\
\hline
\end{tabular}

Tablo8'de verilen bulgulara göre araştırmaya katılan öğrencilerin \%85,6's1 matematik dişındaki derslerde de bu tarz materyaller ile bu tarz uygulamaların yapılmasını istediğini belirtmiş olup, $\% 14,4$ 'ü ise bu tarz uygulamaların diğer derslerde yapılmasını istemediğini ifade etmiştir.

\section{Dönüşüm Çarkı Somut Materyalinin Kullanımına İlişkin Öğretmen Görüşleri}

Araştırmaya katılan 9 öğretmene materyalle ilgili görüşleri sorulmuştur. Öğretmen 5 ve öğretmen 2, 3 yillık mesleki tecrübeye sahip öğretmenlerdir. Diğer öğretmenler ise 10 yıl ve üzeri mesleki tecrübeye sahiptir. Öğretmenlerin materyale ilişkin görüşleri aşağıda sunulmuştur.

Öğrt 1 ve 9: Materyali kullanılabilir bulmuş, uygulamada öğrencilerin bu materyal yardımı ile konuyu pekiştirmeleri ve materyal olmadan soruları çözüp kontrol etmeleri yönünü beğenmiş yoksa öğrencileri ezberciliğe sevk edebileceğini vurgulamıştır.

Öğrt2ve 7: Materyali portatif uygulanabir kullanışlı bulduğunu belirtmiştir.

Öğrt3-4: Materyalin güzel olduğunu fakat konu basit bir konu olduğundan kullanmaya gerek olmadanda öğrencilerin anladığını vurgulamıştır.

Öğrt5: Materyalin güzel ve kullanılabilir kazanımlara hitap ettiğini belirtmiş ancak öğrencilerin kendilerini denedikleri pencerelerin daha büyük olması gerektiğini belirtmişlerdir. 
Öğrt 6 ve 8: Bu konuda materyale çok ihtiyaç duyulduğunu öğrencilerin dönme hareketi uygulanmış cisimlerin şekillerini zihinlerinde canlandırmakta zorlandıklarını belirtmişlerdir.

Öğretmenlerden büyük çoğunluğu materyali faydalı ve kullanılabilir olarak değerlendirirken 1 öğretmen konu basit bir konu olduğundan materyal kullanmaya gerek yoktur yorumunda bulunmuştur. Materyalin geliştirilebilir yönü olarak uygulama yapılan yazılıp silinebilen pencerelerin daha büyük olması yönündedir. Öğrencileri ezbercilikten kurtaran uygulama bölümü ve öğrencilerin kendilerinin de kullanabildiği portatif bir materyal olması öğretmenlerin beğenisini toplamıştır.

\section{SONUÇ VE TARTIŞMA}

Yalnızca ders kitaplarına bağlı kalınarak gerçekleştirilen öğrenme ortamlarında öğrenciler tahminde bulunma, muhakeme etme, sezgisel düşünme, güdülenme, deney yapma, deneyden elde edilen sonucu görme ve formülleri çıkarma becerilerini tam olarak kazanamamaktadırlar. Buna karşın materyallere dayalı öğrenme ortamları bu imkânları büyük ölçüde sağlamaktadır (Gündüz vd. 2008). Araştırmamızda 3 boyutlu düşünmenin ön planda olduğu bir konu olan dönüşüm geometrisi ile ilgili geliştirilen dönüşüm çarkı materyalinin kullanılabilirliği araştırılmıştır. Araştırmada materyale ilişkin ayrı ayrı öğretmen ve öğrenci görüşleri incelenmiştir.

Öğrencilerin büyük çoğunluğu materyali, konunun öğreniminde faydalı bulmuştur. Materyalin kullanımında her hangi bir zorluk yaşamadıklarını belirtmişlerdir. Materyal sayesinde konuyu daha iyi öğrendiğini veya pekiştirdiğini, kendilerine faydalı olduğunu, matematiğe bakış açısında değişikliğe sebep olduğunu ve materyali daha sonra da kullanmak istediklerini belirtmişlerdir.

Öğrenciler geleneksel yöntemlerle, tahtaya bağlı kalınarak geçirilen dersleri sıkıcı bulmakta ve bu sebeple dersleri yeterli ilgi ile dinlememektedir. Bu durum öğrencilerin anlatılanları anlamasında ve kalıcı öğrenme gerçekleştirmesinde engel teşkil etmektedir.Öğrencilerde daha kalıcı öğrenme ve ilgili bir tutum oluşturmak için ders ortamları çeşitli materyaller zenginleştirilmelidir.

Dönüşüm çarkı materyali ile işlenen dersi öğrencilerin çekici bulması dönüşüm çarkı materyalinin istenilen hedefe ulaştığını gösterir niteliktedir. Nitekim, Kennedy ve Tipps (1994) somut materyallerin en zor matematik konularının dahi anlaşılmasını kolaylaştırdığını savunmaktadır. Bozkurt ve Akalın (2010) materyal kullanımının, öğretim programlarının uygulamada başarılı olmasına da yardımcı olmasının yanı sıra dersi sıkıcılıktan kurtararak dersin işlenmesini daha zevkli hale getirebileceğini, zamanın iyi kullanılmasını sağlayabileceğini ve derslerin verimini arttırabileceğini belirtmişlerdir.

Öğrencilerin derslere ilgisini ve katılımını arttırmak için ders ortamlarını ve ders içeriklerini zenginleştirmek öğretmenlerin başlıca görevlerindendir. Öğrencilerin yeni konuları öğrenmelerinde, materyal kullanımı özellikle de öğrencinin aktif olarak sürece katılımını sağlayacak materyallerin kullanımı oldukça önemlidir. Öğrenci öğrenme sürecinin içinde olarak, bire bir katılımlı şekilde konuları öğrenmiş olur. Bu 
sayede öğrenme daha kalıcı ve hatırlanması kolay bir konu haline gelir. Materyalin konuyu daha kalıcı öğretmesi ve öğrenmede kolaylık sağlaması, materyalin kullanılması için öğrencilere teşvik edici unsurlardır.

Araştırmamıza katılan öğretmenlerden büyük çoğunluğu materyali faydalı ve kullanılabilir olarak değerlendirmektedir. Öğretmenlerin etkin bir materyalden bekledikleri önemli özelliklerden bazıları şunlardır; öğrencilerin öğrenmelerini ve uygulamalarını kontrol etmesi, kullanımının rahat ve elverişli olması, uygulama imkânı sağlaması, kendi başına konunun anlaşılmasında yeterli olması ve kolay anlaşılır bir sisteminin olması. Öğrenciler için kullanılabilir bir materyal tasarlanmak istenildiğinde verilen özelliklere dikkat edilmelidir. Bu özelliklerden de anlaşıldığı gibi öğrencilerin materyalden beklediği, materyal ile baş başa kaldıklarında öğrenme ve uygulama ortamını yakalayabilmektir. Bu özellikleri taşıyan materyaller öğrenciler tarafından kullanılmak istenmekte ve öğrencilerin konulara hatta matematik dersine olan ilgisini arttırmaktadır. Kutluca ve Akın, 2013 çalışmalarında benzer olarak öğretmenlerin ve öğretmen adaylarının matematik derslerinde materyal kullanmalarının faydalı bulgularına ulaşmıştır. Araştırmamızda materyal kullanmayı basit bir konu olduğu gerekçesiyle gerekli bulmayan öğretmenimiz bulunmaktadır. Materyal kullanmanın özellikle matematik dersinde somutlaştırmayta yardımcı olduğu ve mümkün oldukça her konuda kullanılması gerekliliğine öğretmenin inanmaması veya bilmemesi, öğretmenlerin çeşitli sebeplerle materyal kullanmaktan kaçındığına işaret eden pek çok çalışmada da bulunmaktadır (Çekirdekçi ve Toptaş, 2011; Dindar ve Yaman, 2003; Kurtdede, 2008).

Araştırmamızda elde ettiğimiz sonuçların, Şahin ve Şimşek'in (1999) ve bir çok araştırmacının (Buruner, 1966, 2006` Dienes ve Golding, 1971; Piaget, 1971; Skemp, 1987) da belirtmiş olduğu 'Öğretmenlerin etkin ve etkileşimli öğrenme ortamlarını tasarlamalarında, öğretim teknolojileri ilkelerine uygun olarak hazırlanmış eğitim materyallerinin kullanımı ' hakkında önem arz eden görüşler ile de paralellik gösterdiği görülmektedir.

Araştırmamızda uyguladığımız yarı yapılandırılmış Görüş Formu ile elde ettiğimiz öğrenci görüşleri Dönüşüm Çarkı materyalinin kullanılabilir bir materyal olduğunu açıkça göstermektedir. Aynı zamanda, dönüşüm geometrisi konusunun öğretiminde ve pekiştirilmesinde öğrencilere fayda sağladığ1 da görülmektedir. Çalışma daha geniş imkânlar altında tekrarlanabilir. Örneğin, bir sınıf ortamında her öğrenci için bir Dönüşüm Çarkı temin edilerek öğrencilerin materyali daha bireysel şekilde kullanmaları ve uygulama yapmaları sağlanabilir. Yahut çalışma süreci daha uzun tutulup, öğrencilere Dönüşüm Çarkı ile daha fazla uygulama yapma fırsatı sağlanabilir. Hatta özgün olarak tasarlanan bu materyalden yola çıkılarak kendilerinin de böyle materyaller tasarlayabileceği yönünde öğrenciler desteklenebilir. 


\section{Kaynakça}

Aksüt, M., Bulut, U. ve Yalvaç, H.İ. (2010). Sınıf öğretmeni adaylarının öğretimi materyalleri tasarımlamalarının incelenmesi, 9. Ulusal Sınıf Öğretmenliği Eğitimi Sempozyumu, 20 -22 Mayıs 2010 (s.513-516). Elazı̆̆.Ankara: Milli Eğitim Bakanlı̆̆ı.

Batdal, G. (2005). Öğrenci odaklı bir yaklaşımla ilköğretim matematik programlarının değerlendirilmesi. XIV. Ulusal Ĕ̆itim Bilimleri Kongresi Kitabı, 343-346.

Bozkurt, A. ve Akalın, S. (2010). Matematik öğretiminde materyal geliştirmenin ve kullanımının yeri, önemi ve bu konuda öğretmenin rolü, Dumlupınar Üniversitesi Eğitim Fakültesi Dergisi, 27, 47-56.

Bozkurt, A., ve Şahin, S. (2013). İlköğretim matematik öğretiminde materyal kullanılırken karşılaşılan zorluklar ve bu zorlukların nedenleri. Mehmet Akif Ersoy Üniversitesi Ĕ̆itim Fakültesi Dergisi, 1(25).

Corte, E. D. (2004). Mainstreams and perspectives in research on learning (mathematics) from instruction. Applied psychology, 53(2), 279-310.

Çekirdekçi, S. ve Toptaş, V. (2011). Sınıf öğretmenlerinin matematik 4. ve 5. Sınıf dersinde öğretim materyalleri kullanımını engelleyen unsurlarla ilgili görüşleri, Pamukkale Üniversitesi Ĕ̆itim Fakültesi Dergisi, 29, 137-149.

Çepni, S. (2010). Araştırma ve Proje Çalışmalarına Giriş. Beşinci Baskı, Trabzon.

Delice, A., Aydın, E., ve Kardeş, D. (2009). Öğretmen adayı gözüyle matematik ders kitaplarında görsel öğelerin kullanımı.

Dindar, H. ve Yaman, S. (2003). İlköğretim okulları birinci kademede fen bilgisiöğretmenlerinin eğitim araç-gereçlerini kullanma durumları, Pamukkaleüniversitesi Ĕ̆itim Fakültesi Dergisi. 13, 167-176

Gündüz, S., ve Odabasi, F. (2004). Bilgi Çaginda Ögretmen Adaylarinin Egitiminde Ögretim Teknolojileri ve Materyal Gelistirme Dersinin Önemi.TOJET: The Turkish Online Journal of Educational Technology, 3(1).

Gündüz, Ş., Emlek, B., ve Bozkurt, A. (2008, May). Computer aided teaching trigonometry using dynamic modelling in high school. In 8th International Educational Technology Conference (pp. 6-7).

Gürbüz, K., ve Durmuş, S. (2009). İlköğretim Matematik Öğretmenlerinin Dönüşüm Geometrisi, Geometrik Cisimler, Örüntü ve Süslemeler Alt Öğrenme Alanındaki Yeterlikleri. Abant İzzet Baysal Üniversitesi Ĕ̆gitim Fakültesi Dergisi.

Gürbüz, K., ve Durmuş, S. (2009). İlköğretim Matematik ÖğretmenlerininDönüşüm Geometrisi, Geometrik Cisimler, Örüntü ve Süslemeler Alt Öğrenme Alanındaki Yeterlikleri. Abant İzzet Baysal Üniversitesi Ĕ̆itim Fakültesi Dergisi.

Güven, B., veKarataş, I. (2003). Dinamik Geometri Yazilimi Cabri ile Geometri Ögrenme: Ögrenci Görüsleri. TOJET: The Turkish Online Journal of Educational Technology, 2(2). 
Heinich, R. (1996). Instructional media and technologies for learning. Simon veSchuster Books For Young Readers.

Hohenwarter, M., ve Fuchs, K. (2004, May). Combination of dynamic geometry, algebra and calculus in the software system GeoGebra. In Computer Algebra Systems and Dynamic Geometry Systems in Mathematics Teaching Conference.

Hohenwarter, M., Jarvis, D., ve Lavicza, Z. (2009). Linking Geometry, Algebra, and Mathematics Teachers: GeoGebra Software and the Establishment of the International GeoGebra Institute. International Journal for Technology in Mathematics Education, 16(2).

Işık, A., ve Konyalıŏlu, A. C. (2005). Matematik eğitiminde görselleştirme yaklaşımı. Kazım Karabekir Eğitim Fakültesi Dergisi, 11, 462-471.

İpek, A. S., ve Baran, D. (2011). İlköğretim Matematik Öğretmen Adaylarinin Teknoloji Destekli Temsillerle İlgili Düşünceleri. In 5th International Computer ve Instructional Technologies Symposium. Retrieved December (Vol. 11, p. 2011).

Jan Gahala, M.A. (2005), Promoting technology use in schools, Erişim tarihi, 21.10.2012,http://www.ncrel.org/sdrs/areas/issues/methods/technlgy/te200.htm

Kabaca, T., Çontay, E. G., ve İymen, E. (2011). Dinamik Matematik Yazılımı ile Geometrik Temsilden Cebirsel Temsile: Parabol Kavramı. Pamukkale Üniversitesi Ĕ̆itim Fakültesi Dergisi, 30(30), 101-110.

Karaağaç, M. K., ve Leyla, K. Ö. S. E. (2015). Öğretmen ve Öğretmen Adaylarının Öğrencilerin Kesirler Konusundaki Kavram Yanılgıları ile İlgili Bilgilerinin İncelenmesi. Sakarya Üniversitesi Ĕ̆itim Fakültesi Dergisi, (30), 81-101.

Kay, R. H., Knaack, L., ve Vaidehi, V. (2008). A multi-component model for assessing learning objects: The learning object evaluation metric (LOEM).Australasian Journal of Educational Technology, 24(5), 574-591.

Kokol-Voljc, V. (2007). Use of mathematical software in pre-service teacher training: The case of dgs. Research into Learning Mathematics, 55.

Kösa, T., ve Karakuş, F. (2010). Using dynamic geometry software Cabri 3D for teaching analytic geometry. Procedia-Social and Behavioral Sciences, 2(2), 1385-1389.

Kurtdede, F. N. (2008). İlköğretimde araç-gereç kullanımına ilişkin öğretmen görüşleri, Afyon Kocatepe Üniversitesi, Kuramsal Ĕ̆itim Bilim Dergisi, 1(1), 48-61.

Milli Ĕ̆itim Bakanlığı (2009). Ilköğgretim matematik dersi (6-8 simıflar) öğretim programı.

Moyer, P. S. (2001). Are we having fun yet? How teachers use manipulatives to teach mathematics. Educational Studies in mathematics, 47(2), 175-197.

Özdemir, İ. E. Y. (2008). Sınıf öğretmeni adaylarının matematik öğretiminde materyal kullanımına ilişkin bilişsel becerileri. Hacettepe Üniversitesi Eğitim Fakültesi Dergisi, 35(35). 
Schibeci, R., Lake, D., Phillips, R., Lowe, K., Cummings, R., ve Miller, E. (2008). Evaluating the use of learning objects in Australian and New Zealand schools. Computers ve Education, 50(1), 271-283.

Tunks, J., ve Weller, K. (2009). Changing practice, changing minds, from arithmetical to algebraic thinking: an application of the concerns-based adoption model (CBAM). Educational Studies in Mathematics, 72(2), 161-183.

Ural, A. (2014) Geometri öğretiminde MS Paint kullanımı. Mehmet Akif ErsoyÜniversitesi Eğitim Fakültesi Dergisi, 29, 92-107.

Yıldırım, S., ve Şahin, T. (1999). Öğretim teknolojileri ve materyal geliştirme.İstanbul: Anı Yayıncılık. 